\title{
Hubungan Antara Rerata Kadar Seng dalam Serum dengan Gejala Klinis Gangguan Pemusatan Perhatian dan Hiperaktivitas pada Anak Berdasarkan Skala Penilaian Perilaku Anak Hiperaktif Indonesia
}

\author{
Rininta Mardiani, Nurmiati Amir, Tjhin Wiguna \\ Departemen Psikiatri, Fakultas Kedokteran Universitas Indonesia/Rumah Sakit Umum Pusat Nasional \\ Dr. Cipto Mangunkusumo, Jakarta
}

\begin{abstract}
Latar belakang. Gangguan Pemusatan Perhatian dan Hiperaktivitas (GPPH) merupakan salah satu gangguan jiwa yang dijumpai pada anak. Terdapat tiga tipe gejala utama GPPH, yaitu kesulitan memusatkan perhatian, hiperaktivitas, dan impulsivitas. Hingga saat ini, belum dapat disimpulkan penyebab pasti terjadinya GPPH. Namun, hasil berbagai penelitian menunjukkan adanya kaitan dengan nutrisi, yaitu adanya defisiensi seng.

Tujuan. Mengetahui perbedaan rerata antara kadar seng dalam serum pada anak dengan GPPH dibandingkan dengan kelompok kontrol anak sehat dan mengetahui hubungan antara rerata kadar seng dalam serum dengan gejala klinis pada anak dengan GPPH.

Metode. Desain penelitian pendekatan metode potong lintang dengan kontrol anak sehat. Penelitian dilakukan di SDN 01 Pagi Kampung Melayu, Jakarta Timur, pada bulan Mei - Juni 2013. Jumlah sampel pada masing-masing kelompok yaitu 42.

Hasil. Didapatkan nilai tengah kadar seng dalam serum untuk kelompok anak GPPH 52,50 $\mu \mathrm{g} / \mathrm{L}$ dan kadar seng dalam serum untuk kelompok anak sehat $51,50 \mu \mathrm{g} / \mathrm{L}$. Tidak ada perbedaan yang bermakna antara kedua nilai tengah kadar seng dalam serum antara kelompok anak yang menderita GPPH dengan anak sehat. Tidak ada hubungan bermakna antara rerata kadar seng dalam darah dengan gejala klinis GPPH. Kesimpulan. Tidak didapatkan perbedaan rerata kadar seng dalam darah antara kelompok anak GPPH dibandingkan dengan anak sehat, dan tidak didapatkan hubungan kadar seng dalam darah pada anak GPPH dengan gejala klinis GPPH yang dinilai berdasarkan Skala Penilaian Perilaku Anak Hiperaktivitas Indonesia (SPPAHI).Sari Pediatri 2014;16(1):17-21.
\end{abstract}

Kata kunci: GPPH, seng serum

\footnotetext{
Alamat korespondensi:

DR. dr. Tjhin Wiguna, Sp.KJ(K). Departemen Psikiatri Fakultas Kedokteran Universitas Indonesia/Rumah Sakit Umum Pusat Nasional Dr. Cipto Mangunkusumo, Jl. Kimia II, Jakarta. Telp. 081287300226. Email:nintanya@yahoo.com
}

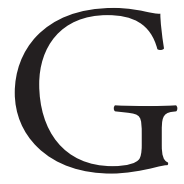
angguan Pemusatan Perhatian dan Hiperaktivitas (GPPH) merupakan salah satu gangguan jiwa yang dijumpai pada anak. Berdasarkan The Diagnostic and Statistical 
Manual of Mental Disorder (DSM-IV) GPPH memiliki tiga tipe yang menggambarkan gejala utama yaitu kesulitan memusatkan perhatian, hiperaktivitas dan impulsivitas. ${ }^{1}$ Prevalensi GPPH di seluruh dunia diperkirakan sebesar 5,29\%. ${ }^{2}$ Di Jakarta, prevalensi GPPH 26,2\% pada anak usia 6-12 tahun. ${ }^{3}$ Kesulitan akademik, bermasalah dalam bersosialisasi, penolakan teman sebaya, ketegangan relasi antara anak dengan orangtua, dan rendah diri menunjukkan ciri anak dengan GPPH. ${ }^{4}$

Hingga saat ini, belum diketahui penyebab pasti terjadinya GPPH. Gangguan pemusatan perhatian dan hiperaktivitas kemungkinan berkaitan dengan defisiensi beberapa mikronutrien di antaranya defisiensi seng. Pada beberapa penelitian, diketahui bahwa seng memiliki peran penting dalam fungsi regulasi transporter dopamine. Seng diyakini secara luas sebagai faktor utama risiko terjadinya GPPH. Oleh karena itu, peneliti ingin mengetahui hubungan antara rerata kadar seng dalam serum antara anak yang menderita GPPH dengan anak sehat dan hubungan antara kadar seng dalam serum dengan gejala klinis GPPH berdasarkan SPPAHI di Jakarta.

\section{Metode}

Penelitian ini dilakukan dengan pendekatan metode potong lintang dengan kontrol anak sehat, yang dilaksanakan di SDN 01 Pagi Kampung Melayu, Jakarta Timur. Pengambilan data dilakukan mulai Mei sampai Juni 2013, dengan jumlah subjek penelitian 42 orang untuk anak dengan GPPH dan 42 orang untuk anak sehat. Metode pengambilan subjek secara acak dan pada kontrol anak sehat dilakukan matching berdasarkan jenis kelamin dan usia.

Kriteria inklusi untuk anak dengan GPPH adalah siswa SD usia 6-12 tahun di SDN 01 Pagi Kampung Melayu Jakarta Timur, laki-laki atau perempuan dengan GPPH, tidak menderita penyakit fisik baik akut maupun kronik, tidak retardasi mental, tidak menderita gangguan jiwa lainnya selain GPPH, pendidikan orangtua siswa minimal tamat Sekolah Menengah Pertama (SMP) dan orangtua serta siswa bersedia mengikuti penelitian.

Kriteria inklusi untuk anak sehat adalah siswa SD usia 6-12 tahun di SDN 01 Pagi Kampung Melayu Jakarta Timur, laki-laki atau perempuan, tidak menderita penyakit fisik baik akut maupun kronik, tidak menderita gangguan jiwa, tidak retardasi mental, pendidikan orangtua siswa minimal tamat Sekolah Menengah Pertama (SMP) dan orangtua serta siswa bersedia mengikuti penelitian.

Seluruh subjek diberikan penjelasan tentang penelitian ini dan subjek terpilih menandatangani lembar persetujuan responden secara tertulis. Pemilihan subjek dilakukan setelah dilakukan penapisan untuk GPPH dengan instrumen Abbreviated Conners Teachers/ Parents Rating Scale (ACPRS), pemeriksaan Raven Coloured Progressive Matrice (RCPM) untuk penapisan retardasi mental, wawancara terstruktur dengan Mini-International Neuropsychiatric Interviewkid (MINI KID) untuk menyingkirkan gangguan jiwa lainnya selain GPPH untuk kriteria inklusi subjek kasus anak dengan GPPH dan menyingkirkan semua gangguan jiwa untuk kriteria inklusi subjek kontrol anak sehat.

Subjek yang masuk dalam kriteria inklusi dan bersedia ikut diminta mengisi lembar kuesioner untuk mendapatkan karakteristik anak dan orangtua. Pada subjek anak dengan GPPH dilakukan pemeriksaan menggunakan instrumen Skala Penilaian Perilaku Anak Hiperaktif Indonesia (SPPAHI) dan dilakukan pemeriksaan kadar seng dalam serum, sedangkan subjek anak sehat sebagai kontrol hanya dilakukan pemeriksaan kadar seng dalam serum. Pemeriksaan kadar seng dalam serum menggunakan metode Inductively Coupled Plasma - Mass Spectrofotometri (ICP-MS) dengan alat agilent 7700 series ICP-MS, yang dilakukan di laboratorium Prodia.

Data dikumpulkan dan dilakukan tabulasi serta diolah secara statistik dengan piranti lunak komputer SPSS 11.5. Kemudian dilakukan analisis deskriptif dan korelasi.

\section{Hasil}

Didapatkan gambaran karakteristik anak dan orangtua dari 42 subjek anak dengan GPPH dan 42 subjek anak sehat yang ikut dalam penelitian (Tabel 1). Tidak terdapat perbedaan rerata antara kadar seng dalam serum pada anak dengan GPPH dibandingkan dengan anak sehat $\mathrm{p}=0,525$ (Tabel 2) dan tidak ada hubungan antara rerata kadar seng dalam serum pada anak dengan GPPH dibandingkan dengan anak sehat $\mathrm{p}=0,862$ (Tabel 3). 
Tabel 2 menunjukkan perbedaan rerata kadar seng dalam serum antara kelompok anak GPPH dengan kelompok anak sehat.
Tabel 3 menunjukkan hubungan antara kadar seng dalam serum dengan gejala klinis GPPH menggunakan SPPAHI.

Tabel 1. Karakteristik demografi subjek penelitian

\begin{tabular}{|c|c|c|}
\hline Karakteristik & $\begin{array}{l}\text { Anak GPPH } \\
\quad(\mathrm{n}=42)\end{array}$ & $\begin{array}{c}\text { Anak sehat } \\
(\mathrm{n}=42)\end{array}$ \\
\hline \multicolumn{3}{|l|}{ Anak } \\
\hline \multicolumn{3}{|l|}{ Jenis kelamin } \\
\hline Laki-laki & $27(64,3)$ & $27(64,3)$ \\
\hline Perempuan & $15(35,7)$ & $15(35,7)$ \\
\hline \multicolumn{3}{|l|}{ Usia (tahun) } \\
\hline Median (min-maks) & $8,00(6-11)$ & $8,00(6-11)$ \\
\hline Kisaran & 6-11 & 6-11 \\
\hline \multicolumn{3}{|l|}{ Indeks masa tubuh } \\
\hline Median (min-maks) & $15,56(12,71-24,49)$ & $14,73(12,71-31,63)$ \\
\hline \multicolumn{3}{|l|}{ Orangtua } \\
\hline \multicolumn{3}{|l|}{ Pendidikan ayah } \\
\hline SMP/Sederajat & $13(13,0)$ & $3(7,1)$ \\
\hline SMU/Sederajat & $25(59,5)$ & $33(78,6)$ \\
\hline Diploma/Sarjana & $4(9,5)$ & $6(14,3)$ \\
\hline \multicolumn{3}{|l|}{ Pendidikan ibu } \\
\hline SMP/Sederajat & $11(26,2)$ & $13(31,0)$ \\
\hline SMU/Sederajat & $26(61,9)$ & $26(61,9)$ \\
\hline Diploma/Sarjana & $5(11,9)$ & $3(7,1)$ \\
\hline \multicolumn{3}{|l|}{ Pekerjaan ayah } \\
\hline Pegawai negeri sipil (PNS) & $0(0,0)$ & $0(0,0)$ \\
\hline Pegawai swasta & $22(52,4)$ & $24(57,1)$ \\
\hline Pedagang & $16(38,1)$ & $12(28,6)$ \\
\hline TNI/Polisi & $0(0,0)$ & $0(0,0)$ \\
\hline Tidak Bekerja & $(2,4)$ & $1(2,4)$ \\
\hline Lain-lain & $3(7,1)$ & $5(11,9)$ \\
\hline \multicolumn{3}{|l|}{ Pekerjaan Ibu } \\
\hline Pegawai negeri sipil (PNS) & $0(0,0)$ & $2(4,8)$ \\
\hline Pegawai swasta & $4(9,5)$ & $3(7,1)$ \\
\hline Dagang & $1(2,4)$ & $1(2,4)$ \\
\hline TNI/Polisi & $0(0,0)$ & $0(0,0)$ \\
\hline Tidak bekerja & $36(85,7)$ & $35(83,3)$ \\
\hline Lain-lain & $1(2,4)$ & $1(2,4)$ \\
\hline \multicolumn{3}{|l|}{ Status pernikahan } \\
\hline Menikah & $40(95,2)$ & $39(92,9)$ \\
\hline Cerai hidup & $1(2,4)$ & $2(4,8)$ \\
\hline Cerai mati & $1(2,4)$ & $1(2,4)$ \\
\hline \multicolumn{3}{|l|}{ Status ekonomi } \\
\hline Rendah & $1(2,4)$ & $1(2,4)$ \\
\hline Menengah ke bawah & $34(81,0)$ & $33(78,6)$ \\
\hline Menengah ke atas & $5(4,8)$ & $8(19,0)$ \\
\hline Tinggi & $2(4,8)$ & $0(0,0)$ \\
\hline
\end{tabular}


Rininta Mardiani dkk: Hubungan antara rerata kadar seng dalam serum dengan gejala klinis GPPH berdasarkan SPPAHI

Tabel 2. Kadar seng dalam serum pada kelompok GPPH dan kelompok kontrol

\begin{tabular}{lccc}
\hline & $\begin{array}{c}\text { Kelompok GPPH } \\
(\mu \mathrm{g} / \mathrm{L})\end{array}$ & $\begin{array}{c}\text { Kelompok anak sehat } \\
(\mu \mathrm{g} / \mathrm{L})\end{array}$ & $\mathrm{p}$ \\
\hline Nilai tengah & 52,50 & 51,50 & $0,525^{*}$ \\
Kisaran & $37-95$ & $34-95$ & \\
\hline
\end{tabular}

*Mann-Whitney U-Test

Tabel 3. Hubungan antara rerata kadar seng dalam serum dengan gejala klinis GPPH

\begin{tabular}{lccc}
\hline & $\begin{array}{c}\text { Kelompok GPPH } \\
(\mu \mathrm{g} / \mathrm{L})\end{array}$ & Nilai SPPAHI & $\mathrm{p}$ \\
\hline Nilai tengah & 52,50 & 34 & $0,862^{*}$ \\
Kisaran & $37-95$ & $20-91$ & \\
\hline
\end{tabular}

* Spearman's

\section{Pembahasan}

Enampuluh empat koma tiga persen anak dengan GPPH adalah laki-laki. Sesuai dengan literatur yang menyatakan bahwa proporsi terjadinya GPPH pada anak laki-laki lebih besar dibandingkan dengan anak perempuan. ${ }^{4}$ Sebagian besar orangtua anak dengan GPPH adalah menikah 95,2\%. Sebaliknya, pada penelitian dilaporkan bahwa sebagian besar anak dengan GPPH mempunyai orangtua tunggal atau bercerai. Status ekonomi menengah ke bawah terdapat $81 \%$ anak dengan GPPH. Status ekonomi tersebut hampir sama dengan penelitian lain yang juga melaporkan status ekonomi rendah anak dengan GPPH. Penelitian kami menunjukkan bahwa 59,5\% ayah dan $61,9 \%$ ibu memiliki jenjang pendidikan sekolah menengah ke atas. Dikatakan tingkat pendidikan orangtua yang rendah pada suatu penelitian banyak terjadi pada anak dengan GPPH. Hasil penelitian menunjukkan 85,7\% ibu tidak bekerja dan 52,4\% ayah bekerja. Berbeda dengan laporan sebuah penelitian yang menyatakan bahwa kedua orangtua bekerja banyak dijumpai pada anak dengan GPPH. ${ }^{5}$

Didapatkan hasil nilai tengah kadar seng dalam

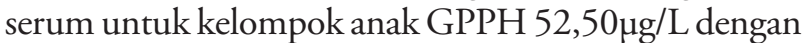
kisaran 37-95 $\mu \mathrm{g} / \mathrm{L}$ dan kadar seng dalam serum untuk kelompok anak sehat $51,50 \mu \mathrm{g} / \mathrm{L}$ dengan kisaran 34$95 \mu \mathrm{g} / \mathrm{L}$, dengan rentang nilai normal kadar seng dalam serum berkisar antara 48-129 $\mu \mathrm{g} / \mathrm{L}$. Didapatkan 12 orang anak mengalami defisiensi kadar seng dalam serum dari 42 subjek penelitian anak dengan GPPH, sedangkan pada anak sehat, 11 orang anak mengalami defisiensi kadar seng dalam serum. ${ }^{6}$
Hasil penelitian menunjukkan tidak adanya perbedaan antara rerata kadar seng dalam serum pada anak dengan GPPH dibandingkan dengan anak sehat. Hal tersebut berbeda dengan penelitian yang pernah dilakukan sebelumnya oleh Bekaroglu dkk ${ }^{7}$ di Turki, dengan subyek penelitian 48 anak dengan GPPH dan 45 anak sehat sebagai kontrol, didapatkan hasil rerata kadar seng dalam serum pada anak dengan GPPH 60,6 +/-9,9 $\mu \mathrm{g} / \mathrm{dL}$ dibandingkan dengan kelompok kontrol 105,8 $+/-13,2 \mu \mathrm{g} / \mathrm{dL}$, dengan rentang nilai normal 70-150 $\mu \mathrm{g} /$ dL. Begitu pula penelitian yang dilakukan Arnold $\mathrm{dkk}^{8}$ di Amerika Serikat, dinyatakan bahwa dari 48 subyek anak dengan GPPH mengalami defisiensi kadar seng yang ditandai dengan 33 anak memiliki kadar seng dalam serum di bawah $88 \mu \mathrm{g} / \mathrm{dL}$ dengan rentang nilai normal kadar seng dalam serum 66-110 $\mu \mathrm{g} / \mathrm{dL}$, dengan rerata kadar seng dalam serum $79 \mu \mathrm{g} / \mathrm{dL}$.

Hasil penelitian menunjukkan tidak ada hubungan antara kadar seng dalam serum dengan gejala klinis GPPH yang dinilai menggunakan instrumen SPPAHI. Temuan ini berbeda dengan penelitian sebelumnya yang telah dilakukan, di antaranya di Amerika Serikat dan Turki yang menyatakan ada hubungan antara defisiensi kadar seng dalam serum pada anak GPPH dengan gejala klinis GPPH menggunakan instrumen yang sudah divalidasi di negara tersebut. Penelitian yang dilakukan oleh Arnold $\mathrm{dkk}^{8}$ menyatakan bahwa ada hubungan antara kadar seng dalam serum pada anak dengan GPPH, dengan gejala klinis GPPH yang dinilai menggunakan Conners parents/teachers rating scales. Didapatkan hubungan antara kadar seng dalam serum dengan inatensi, tetapi tidak didapatkan hubungan dengan gejala hiperaktivitas-impulsivitas. 


\section{Kesimpulan}

Tidak didapatkan perbedaan antara rerata kadar seng dalam darah pada kelompok anak GPPH dibandingkan dengan anak yang sehat. Nilai tengah kadar seng dalam darah pada anak GPPH 52,50 $\mu$ gram/L dan anak sehat $51,50 \mu \mathrm{gram} / \mathrm{L}$. Tidak didapatkan hubungan rerata kadar seng dalam darah pada anak GPPH dengan gejala klinis GPPH yang dinilai berdasarkan Skala Penilaian Perilaku Anak Hiperaktivitas Indonesia (SPPAHI).

\section{Daftar pustaka}

1. American Psychiatric Association. Diagnostic and Statistical Manual of Mental Disorders. Fourth Edition. Text Revision. Washington DC: American Psychiatric Association; 2000.

2. Polanczyk G, Silva de Lima M, Horta BL, Biederman J, Rhode LA. The world-wide prevalence of ADHD: A systematic review and metaregression analysis. Am J
Psychiatry 2007;164:942-8.

3. Saputro D. Attention deficit/hyperactivity disorder. Jakarta: CV. Sagung Seto;2009.

4. Harpin AV. The effect of ADHD on the life of an individual, their family, and community from preschool to adult life. Arch Dis Child 2005;90Suppl 1:2-7.

5. Frank-Briggs AI. Attention deficit hyperactivity disorder (ADHD). J Pediatr Neurol 2011;9:291-8.

6. Arnold LE, DiSilvestro RA. Zinc in attentiondeficit/hyperactivity disorder. J Child and Adolesc Psychopharmacol 2005;15:619-27.

7. Bekaroglu M, Aslan Y, Gedik Y, Deger O, Mocan H, Erduran E, dkk. Relationships between serum free fatty acids and zinc, and attention deficit hyperactivity disorder: a research note. J Child Psychol Psych 1996;37:225-7.

8. Arnold LE, Bozzolo H, Hollway J, Cook A, DiSilvestro RA, Bozzolo DR, dkk. Serum zinc correlates with parent and teacher-rated inattention in children with attention-deficit/hyperactivity disorder. J Child Adolesc Psychopharmacol 2005:15:628-35. 